\title{
Ewa Kowalewska-Borys
}

Uniwersytet w Białymstoku e-mail: kowalewska-borys@uwb.edu.pl telefon: +48 857457160

Aneta Michałowska

Asesor Prokuratury Rejonowej Warszawa-Mokotów w Warszawie telefon: +4822 2171300

DOI: $10.15290 / \mathrm{mhi} .2014 .13 .02 .13$

\section{Karnoprocesowe uprawnienia osób pozostających w związkach partnerskich homoseksualnych}

\author{
SUMMARY \\ Rights of Individuals Joined in a Civil Union in View of the Law \\ of Criminal Procedure
}

The article is an analysis of the rights which can be exercised in Polish criminal procedure by same-sex couples joined in a civil union. The key idea of the deliberation is an assertion that in criminal procedure - on account of the so called criminal procedure relation - the rights of people joined in same-sex unions are protected well enough, therefore alterations of the presented regulations are unnecessary. The authors make an argument, starting with demonstrating the legal definition of a closest person, next describing the following laws: the right to access the files of a case, the right to refuse to testify, the right to be excused from testifying, the right of succession after a deceased party of the proceedings, the right to appointed counsel, the right to apply for remand of a suspected person, the right to be notified of a preventive detention and to deposit bail, and to take part in a trial.

Key words: same-sex couples, criminal procedure, the right to access the files of a case, the right to refuse to testify, the right to be excused from testifying, the right of succession after a deceased party of the proceedings, the right to appointed counsel, the right to apply for remand of a suspected person, the right to be notified of a preventive detention and to deposit bail, and to take part in a trial

Słowa kluczowe: homoseksualne związki partnerskie, postępowanie karne, prawo dostępu do akt sprawy, prawo odmowy składania zeznań, prawo do zwolnienia od złożenia zeznania lub odpowiedzi na pytanie, prawo wykonywania po śmierci osoby najbliższej praw, które by jej przysługiwały w postępowaniu, prawo do ustanowienia obrońcy, prawo do występienia $z$ wnioskiem o zastosowanie tymczasowego aresztowania osoby podejrzanej, prawo do otrzymania zawiadomienia o zastosowaniu tymczasowego aresztowania osoby najbliższej, prawo do złożenia poręczenia majątkowego, prawo do uczestniczenia $\mathrm{w}$ rozprawie 
Na wstępie wypada zauważyć, że kwestie związane z uprawnieniami osób pozostających $\mathrm{w}$ tzw. związkach partnerskich $\mathrm{w}$ toku postępowania karnego nie budzą większych kontrowersji. Zapewne wynika to $\mathrm{z}$ faktu, iż karnoprocesowe uprawnienia osób pozostających $\mathrm{w}$ tego rodzaju związkach $\mathrm{w}$ zasadzie nie odbiegają od uprawnień osób pozostających w związkach sformalizowanych (małżeńskich). Należy zauważyć, iż przepisy ustawy z 6 czerwca 1997 roku Kodeks postępowania karnego ${ }^{1}$ dają w zasadzie tożsame uprawnienia osobom najbliższym dla stron postępowania karnego, niezależnie od tego, czy pozostają one w związku małżeńskim, czy też tworzą związek partnerski. Wydaje się, że kluczowe znaczenie dla zakreślonego na wstępie przedmiotu rozważań ma przede wszystkim ustawowa definicja terminu „osoba najbliższa" (art. 115 §11 k.k.). W kontekście zaś rozważań o uprawnieniach w zakresie postępowania karnego osób pozostających w związkach partnerskich należałoby jednakże mieć na uwadze, iż $w$ praktyce możemy wyróżnić dwie grupy związków partnerskich, a mianowicie związki tworzone przez osoby różnych płci (heteroseksualne, konkubinaty) oraz związki osób tej samej płci (homoseksualne). Rozróżnienie takie ma znaczenie $\mathrm{w}$ praktyce, ponieważ $\mathrm{w}$ orzecznictwie i doktrynie zaznaczają się pewne rozbieżności w podejściu do uprawnień karnoprocesowych partnerów pozostających $\mathrm{w}$ związkach heteroseksualnych oraz homoseksualnych. Powstaje zatem zupełnie zasadnicze pytanie, czy różnice te nie są na tyle istotne, aby mogły powodować poważne zastrzeżenia pod adresem ustawodawcy. Paradoksalnie przedmiotowe rozważania uzasadnia również publiczna dyskusja o projekcie ustawy o związkach partnerskich. Oczywiście perspektywa karnoprocesowa jest raczej drugorzędna, ale irytujące są próby nadania jej dyletanckiego oraz ignoranckiego charakteru.

Rozważania dotyczące uprawnień, jakie przysługują $\mathrm{w}$ toku postępowania karnego osobom pozostającym w związkach partnerskich nie mogą być prowadzone w oderwaniu od przepisów prawa karnego materialnego, zwłaszcza iż to właśnie $\mathrm{w}$ tej regulacji należy upatrywać źródła różnic $\mathrm{w}$ traktowaniu partnerów ze związków partnerskich heteroseksualnych i homoseksualnych. Źródłem tych różnic są bowiem rozbieżności w wykładni pojęcia „osoba najbliższa", a ściślej mówiąc - jednego z elementów definicji legalnej tego pojęcia, a mianowicie "osoby pozostającej we wspólnym pożyciu”.

Definicja legalna pojęcia "osoba najbliższa” sformułowana została $\mathrm{w}$ art. $115 \S 11$ k.k. W myśl powołanego przepisu osobą najbliższą jest małżonek, wstępny, zstępny, rodzeństwo, powinowaty w tej samej linii lub stopniu, osoba pozostająca w stosunku przysposobienia oraz jej małżonek, a także osoba pozostająca we wspólnym pożyciu. Wskazać należy, iż zaliczenie konkretnej osoby do jednej z kategorii krewnych lub powinowatych nie nastręcza większych trudności. Rozbieżności interpretacyjne budzi jedynie ustalenie, czy

1 Dz. U. z 1997 r. Nr 89, poz. 555 z późn. zm. 
dana osoba może być zaliczona do kategorii „osób pozostających we wspólnym pożyciu".

W tym kontekście wskazać wypada, iż w okresie obowiązywania kodeksu karnego z 1969 roku w orzecznictwie Sądu Najwyższego wyrażony został pogląd, że za istotne oraz konieczne elementy wspólnego pożycia w rozumieniu ówczesnego art. 120 §5 k.k. z 1969 roku należy uznać wspólne pożycie psychiczne i fizyczne, wspólnotę ekonomiczną oraz trwałość związku. Te bowiem elementy mogą wskazywać, że pomiędzy dwiema osobami płci odmiennej zachodzi taki związek, który od związku małżeńskiego różni się tylko brakiem prawnej legalizacji faktycznego związku małżeńskiego ${ }^{2}$. W podobny sposób kwestia ta była przedstawiana także w przeważającej części literatury, co skutkowało przyjmowaniem, że we wspólnym pożyciu pozostają wyłącznie osoby żyjące $\mathrm{w}$ konkubinacie ${ }^{3}$. Niejako obok tego stanowiska pojawiał się również pogląd, zgodnie z którym dla przyjęcia pozostawania we wspólnym pożyciu nie jest konieczne wspólne zamieszkiwanie oraz prowadzenie wspólnego gospodarstwa domowego ${ }^{4}$, a niektórzy przedstawiciele doktryny prezentowali nawet radykalne stanowisko, że wystarczające jest stałe pożycie seksualne ${ }^{5}$. W doktrynie nadal jednak najbardziej sporna jest kwestia, czy we wspólnym pożyciu w rozumieniu art. 115 §11 k.k. mogą pozostawać osoby tej samej płci. Możliwość taką neguje A. Zoll, który odwołuje się nie tylko do naszych uwarunkowań kulturowych ${ }^{6}$, ale również analogii wspólnego pożycia do małżeństwa, a zatem związku osób odmiennej płci ${ }^{7}$. Stanowisko to było zbieżne co do zasady ze stanowiskiem Sądu Najwyższego ${ }^{8}$, który uznał, iż pojęcie wspólnego pożycia odnoszone jest wyłącznie do konkubinatu, a w szczególności do związku osób o różnej płci, odpowiadającego od strony faktycznej stosunkowi małżeństwa (którym w myśl art. 18 Konstytucji RP jest wyłącznie związek osób różnej płci). Jednakże obecnie w doktrynie coraz powszechniejsze stają się poglądy, które opowiadają się za przyznaniem przymiotu pozostawania we wspólnym pożyciu dwóm osobom tej samej płci. Przedstawiciele tego nurtu stoją na stanowisku, że pojęcie wspólnego pożycia jest podmiotowo szersze od pojęcia konkubinatu i obejmuje swoim za-

Wyrok SN z 12 listopada 1975 r., V KR 203/75, OSP 1976, z. 10, poz. 187.

3 Zob. np. W. Wolter, [w:] I. Andrejew, W. Świda, W. Wolter, Kodeks karny z komentarzem, Warszawa 1973, s. 377; M. Siewierski, [w:] J. Bafia, K. Mioduski, M. Siewierski, Kodeks karny. Komentarz, Warszawa 1971, s. 361.

4 Zob. Z. Doda, A. Gaberle, Dowody w procesie karnym, Warszawa 1995, s. 215.

5 Zob. J. Gajek, O pojęciu faktycznego wspólnego pożycia w prawie karnym, „Palestra” 1972, nr 3, s. 46.

6 Zob. A. Zoll, [w:] A. Zoll, G. Bogdan, Z. Ćwiąkalski, P. Kardas, J. Majewski, J. Raglewski, M. Szewczyk, W. Wróbel, Kodeks karny. Część ogólna. Komentarz, t. 1: Komentarz do art. 1-116 k.k., Kraków 2004, s. 508.

7 Ibidem, s. 634.

8 Zob. postanowienie SN z 7 lipca 2004 r., II KK 176/04, LEX nr 121668. 
kresem także tzw. związki partnerskie homoseksualne, które zgodnie z poglądami przedstawicieli doktryny prawa cywilnego nie stanowią konkubinatu (nieformalnego odpowiednika małżeństwa), ponieważ są relacją między osobami tej samej płci ${ }^{9}$.

Odnosząc się do uprawnień karnoprocesowych osób pozostających w związkach partnerskich należy mieć na uwadze, iż zależą one od charakteru/roli, w jakiej w postępowaniu karnym występuje/występowała osoba pozostająca $w$ takim związku. Inne bowiem uprawnienia będą przysługiwać partnerowi/partnerce pokrzywdzonego, czy też podejrzanego/oskarżonego, a inne partnerowi/partnerce występującemu jedynie $w$ charakterze świadka. Trzeba również podnieść, iż ze względu na dominujące w doktrynie i orzecznictwie wąskie rozumienie pojęcia pozostawania we wspólnym pożyciu i zaliczanie do tej kategorii wyłącznie konkubinatów w zakresie uprawnień pokrzywdzonego prawa osób pozostających w homoseksualnych związkach partnerskich będą doznawać pewnych ograniczeń.

W rozważanym kontekście wskazać należy przepis art. $52 \S 1$ k.p.k., który stanowi, że $\mathrm{w}$ razie śmierci pokrzywdzonego prawa, które by mu przysługiwały, mogą wykonywać osoby najbliższe, natomiast w sytuacji, gdy organ prowadzący postępowanie dysponuje informacjami o osobach najbliższych dla pokrzywdzonego, powinien pouczyć o przysługujących uprawnieniach przynajmniej jedną $\mathrm{z}$ nich. Wskazać $\mathrm{w}$ tym miejscu wypada, iż w przypadku, gdy jest kilka osób najbliższych, to każda z nich, niezależnie od siebie, może wykonywać prawa przysługujące oskarżonemu (podejrzanemu) ${ }^{10}$. Podobnie, zgodnie z przepisem art. 58 §1 k.p.k., w przypadku śmierci pokrzywdzonego oskarżyciela posiłkowego, osoby najbliższe mogą przystąpić do postępowania $\mathrm{w}$ charakterze oskarżyciela posiłkowego $\mathrm{w}$ każdym stadium postępowania. Nadmienić wypada, iż dotyczy to zarówno oskarżyciela posiłkowego ubocznego, jak i oskarżyciela posiłkowego subsydiarnego.

Rozróżnienie to ma istotne znaczenie $\mathrm{z}$ punktu widzenia karnoprocesowych uprawnień osób pozostających w związkach partnerskich, ponieważ inna jest regulacja prawna dotycząca wstąpienia osób najbliższych w prawa zmarłego oskarżyciela posiłkowego ubocznego, a inna dotycząca oskarżyciela subsydiarnego. Wskazać należy, iż zgodnie z treścią art. 58 §1 k.p.k. śmierć oskarżyciela ubocznego nie tamuje biegu postępowania, a osoby najbliższe mogą wstąpić do procesu aż do jego prawomocnego zakończenia. Przepis ten znajduje również zastosowanie w sytuacji, gdy wcześniej oskarżyciel publiczny odstąpił od oskarżenia. Wynika to z faktu, że zgodnie z treścią art. 14 \$2 k.p.k.

9 M. Mozgawa (red. nauk.), M. Budyn-Kulik, P. Kozłowska-Kalisz, M. Kulik, Kodeks karny. Komentarz, teza 4 do art. 115 \$11 k.k., Lex, 2013; podobnie J. Wojciechowski, Kodeks karny. Komentarz. Orzecznictwo, Warszawa 1997, s. 206; A. Marek, Komentarz do kodeksu karnego. Część ogólna, Warszawa 1999, s. 306; J. Majewski, [w:] G. Bogdan (i in.), op. cit., s. 1446.

10 Postanowienie SN z 26 października 2011 r., I KZP 11/11, „Prokuratura i Prawo” - wkł. 2012/1/3. 
sąd nie jest związany odstąpieniem oskarżyciela publicznego od oskarżenia, a tym samym śmierć oskarżyciela posiłkowego ubocznego, który występował sam po stronie oskarżenia, nie może spowodować umorzenia postępowania na podstawie art. $61 \S 2$ k.p.k. $w$ zw. z art. 58 §2 k.p.k. Przepis art. 58 §1 k.p.k. ma zastosowanie również $\mathrm{w}$ razie śmierci oskarżyciela posiłkowego ubocznego, który przystąpił do procesu na podstawie art. $55 \S 3$ k.p.k., a w procesie działa cały czas oskarżyciel posiłkowy subsydiarny. Natomiast przepis art. 58 §2 k.p.k. odnosi się do oskarżyciela, który samodzielnie popierał oskarżenie. Dotyczy on więc oskarżyciela posiłkowego subsydiarnego oraz oskarżyciela posiłkowego ubocznego, działającego na podstawie art. 55 §3 k.p.k., wówczas gdy uprzednio oskarżyciel posiłkowy subsydiarny odstąpił od oskarżenia, a zmarły oskarżyciel był jedynym podmiotem działającym po stronie oskarżenia. W takiej sytuacji odpowiednio stosuje się art. 61 k.p.k., a zatem postępowanie karne zawiesza się z urzędu, a osoby najbliższe mogą wstąpić $\mathrm{w}$ prawa zmarłego $\mathrm{w}$ terminie zawitym 3 miesięcy od dnia śmierci oskarżyciela. Dopiero wówczas gdy w tym terminie osoba uprawniona nie wstąpi $\mathrm{w}$ prawa zmarłego, sąd umarza postępowanie. Wstąpienie $\mathrm{w}$ prawa zmarłego jednego $\mathrm{z}$ uprawnionych nie pozwala na wstąpienie pozostałych $\mathrm{w}$ prawa strony zastępczej ${ }^{11}$.

Powoływany powyżej art. 61 k.p.k. reguluje kwestie związane z uprawnieniami osób najbliższych $\mathrm{w}$ przypadku śmierci pokrzywdzonego będącego oskarżycielem prywatnym. Jak już wskazano wcześniej, zgodnie z tym przepisem $\mathrm{w}$ razie śmierci oskarżyciela prywatnego postępowanie zawiesza się, a osoby najbliższe mogą $w$ terminie 3 miesięcy od dnia śmierci oskarżyciela prywatnego wstąpić $\mathrm{w}$ prawa zmarłego. Jeżeli tego nie uczynią sąd umarza postępowanie.

W toku postępowania karnego pokrzywdzony może występować również $\mathrm{w}$ roli powoda cywilnego. Dzieje się tak wówczas, jeżeli do czasu rozpoczęcia przewodu sądowego na rozprawie głównej wytoczy on przeciw oskarżonemu powództwo cywilne $\mathrm{w}$ celu dochodzenia $\mathrm{w}$ postępowaniu karnym roszczeń majątkowych (art. 62 k.p.k.). W razie śmierci pokrzywdzonego, który nie wytoczył powództwa cywilnego, osoby najbliższe - na podstawie art. 63 §1 k.p.k. - mogą aż do czasu rozpoczęcia przewodu sądowego wytoczyć powództwo cywilne o przysługujące im roszczenia majątkowe wynikające z popełnienia przestępstwa. W takiej sytuacji osoby najbliższe, tzw. strony zastępcze, mogą domagać się roszczeń, które dla nich wywodzą się bezpośrednio z przestępstwa, a nie roszczeń, jakie przysługiwałyby pokrzywdzonemu. Natomiast $\mathrm{w}$ razie śmierci pokrzywdzonego - powoda cywilnego, osoby najbliższe mogą wstą-

11 J. Grajewski (red.), S. Steinborn, Komentarz aktualizowany do art. 58 Kodeksu postępowania karnego [w:] J. Grajewski (red.), L. K. Paprzycki, S. Steinborn, Komentarz aktualizowany do art. 1-424 ustawy $z$ dnia 6 czerwca 1997 r. Kodeks postępowania karnego (Dz. U. 97.89.555), LEX/el., 2013. 
pić w prawa zmarłego i dochodzić przysługujących im roszczeń, przy czym w przypadku niewstąpienia tych osób postępowanie karne jest kontynuowane, a jedyną konsekwencją jest to, iż sąd, wydając orzeczenie kończące postępowanie, pozostawia powództwo cywilne bez rozpoznania (art. 63 \$2 k.p.k.). $\mathrm{W}$ takiej sytuacji tzw. strony nowe (osoby najbliższe, które wstąpiły w prawa powoda cywilnego) mogą domagać się nie tylko roszczeń, które im przysługują, ale mogą także dochodzić roszczeń w zakresie objętym, wniesionym przez zmarłego pokrzywdzonego powództwem adhezyjnym, które przysługiwałyby mu, gdyby żył. W przypadku śmierci pokrzywdzonego, niezależnie od momentu, w którym ona nastąpiła, orzekanie w części dotyczącej roszczeń zmarłego powoda cywilnego z oczywistych względów może być utrudnione lub wręcz niemożliwe ${ }^{12}$. W tym kontekście zauważyć również należy, iż zgodnie z treścią art. 64 k.p.k. powództwo cywilne na rzecz osoby najbliższej, o której mowa w art. $63 \S 1$ k.p.k., może wytoczyć prokurator, jeżeli wymaga tego interes społeczny.

Kolejną grupę uprawnień, jakie przysługują w postępowaniu karnym osobom pozostającym w związkach partnerskich, stanowią uprawnienia związane $\mathrm{z}$ występowaniem danej osoby/partnera $\mathrm{w}$ charakterze podejrzanego/oskarżonego. W tym miejscu wskazać wypada, iż w odniesieniu do tej kategorii uprawnień fakt, czy jest to związek partnerski osób tej samej, czy też różnej płci w zasadzie nie ma znaczenia $\mathrm{w}$ praktyce.

W tym kontekście przywołać należy przede wszystkim przepis art. 83 \$1 k.p.k., zgodnie z którym $\mathrm{w}$ toku postępowania karnego obrońcę ustanawia oskarżony. Jednakże do czasu ustanowienia obrońcy przez oskarżonego pozbawionego wolności, obrońcę może ustanowić inna osoba, o czym niezwłocznie zawiadamia się oskarżonego. Zgodnie z powołanym przepisem obrońcę dla oskarżonego (podejrzanego) pozbawionego wolności może ustanowić każda osoba, a więc również partner/partnerka w przypadku związków partnerskich, i to niezależnie od tego, czy osobę tę można zaliczyć do kategorii „osób pozostających we wspólnym pożyciu", czy też nie. Kwestia ta była odmiennie uregulowana w kodeksie karnym z 1969 roku, gdyż art. 73 §1 d.k.p.k. stanowił, że dla oskarżonego pozbawionego wolności obrońcę mogła ustanowić jedynie osoba najbliższa ${ }^{13}$.

Z kolei zgodnie z treścią art. 182 §1 k.p.k. osoba najbliższa dla oskarżonego może odmówić zeznań. Prawo do odmowy zeznań trwa mimo ustania małżeństwa lub przysposobienia (art. 182 §2 k.p.k.). Regulacja ta wyraźnie wskazuje na doniosłą rolę terminu „wspólne pożycie” z jednej strony oraz od-

12 J. Grajewski (red.), S. Steinborn, Komentarz aktualizowany do art. 63 Kodeksu postępowania karnego, [w:] J. Grajewski (red.), L. K. Paprzycki, S. Steinborn, op. cit.

13 Ustawa z 19 kwietnia 1969 r. Kodeks postępowania karnego (Dz. U. z 1969 r. Nr 13, poz. 96 z późn. zm.). 
mienność sytuacji prawnej partnerów hetero- i homoseksualnych ${ }^{14}$. W orzecznictwie w odniesieniu do związków partnerskich heteroseksualnych wskazuje się, iż skoro uznanie związku istniejącego między kobietą a mężczyzną za konkubinat uzależnione jest od spełnienia określonych warunków, to odmowa zeznań przez świadka z tego powodu nakłada na sąd orzekający obowiązek poczynienia stosownych ustaleń co do charakteru tego związku ${ }^{15}$, nie tylko $\mathrm{w}$ czasie czynu, ale również $\mathrm{w}$ czasie składania zeznañ ${ }^{16}$. Powyższe ustalenie ma istotne znaczenie, ponieważ przy ocenie, czy pomiędzy pokrzywdzoną a oskarżonym istniały więzi uzasadniające przyjęcie faktycznego małżeństwa, będącego podstawą do odmowy składania zeznań, należy brać pod uwage układ stosunków z daty czynu, a nie ten, który istniał wcześniej lub kształtował się $\mathrm{w}$ toku postępowania sądowego ${ }^{17}$. Jednakże obecnie wśród przedstawicieli doktryny aktualne są głosy, iż prawo do odmowy składania zeznań na podstawie art. $182 \S 1$ k.p.k. przysługuje także osobom pozostającym w związkach partnerskich osób tej samej płci ${ }^{18}$.

Prawo odmowy zeznań odnosi się do całości zeznań, co oznacza, że osoba najbliższa $\mathrm{w}$ ogóle nie występuje $\mathrm{w}$ sprawie $\mathrm{w}$ charakterze świadka, przestaje w sprawie istnieć jako osobowe źródło dowodowe. Świadek, który skorzysta $\mathrm{z}$ prawa odmowy zeznań, przestaje $\mathrm{w}$ sprawie istnieć jako osobowe źródło dowodowe. Żadne jego wypowiedzi nie mogą być w procesie odtworzone, bez względu na to, jak zostały utrwalone, czy to za pomocą protokołu, taśmy magnetofonowej, filmu, fotografii czy innych środków, np. utrwaleń audiowizualnych. Wszelkie próby odtworzenia tych zeznań, zarówno za pomocą świadków, jak urządzeń technicznych, są obejściem ustawy. Dopuszczenie możliwości odtwarzania wypowiedzi lub zachowań takiej osoby nie dotyczy jej zeznań, ale wypowiedzi poza procesem ${ }^{19}$. Prawo odmowy składania zeznań przysługuje jedynie $\mathrm{w}$ odniesieniu do tego oskarżonego, którego relacje ze świadkiem rodzą uprawnienie, o którym mowa w art. 182 §1 k.p.k. $\mathrm{W}$ odniesieniu do pozostałych oskarżonych świadek ten obowiązany jest składać zeznania. Zasada ta działa jednakże tylko wówczas, gdy możliwe jest od-

14 W orzecznictwie dotyczącym omawianego przepisu wskazuje się, iż za istotne i konieczne elementy wspólnego pożycia w rozumieniu art. 120 §5 k.k. uznać należy następujące: wspólne pożycie psychiczne i fizyczne, wspólnotę ekonomiczną i trwałość związku. Te elementy bowiem wskazywać mogą, że pomiędzy dwiema osobami płci odmiennej zachodzi taki związek, który od związku małżeńskiego różni się tylko brakiem prawnej legalizacji faktycznego związku małżeńskiego, zob. wyrok SN z 12 listopada 1975 r., V KR 203/75, OSPiKA 1976, z. 10, poz. 187. Wyrok SN z 31 marca 1988 r., I KR 50/88, OSNKW 1988, nr 9-10, poz. 71

Wyrok SA w Katowicach z 15 marca 2007 r., II AKa 24/07, „Prokuratura i Prawo” 2007/11/26.

Wyrok SA w Szczecinie z 21 grudnia 2006 r., II AKa 157/06, LEX nr 283401.

Zob. A. Siostrzonek-Sergiel, Partnerzy w zwiazkach homoseksualnych a "osoby najbliższe" w prawie karnym, PiP 2011, z. 4, s. 73.

Wyrok SA w Krakowie z 17 listopada 2011 r., II Aka 220/11, KZS 2011, z. 11, poz. 36. 
dzielenie zeznań tego świadka względem innych oskarżonych, tak by relacje procesowe dotyczące tych oskarżonych nie pogarszały sytuacji osoby najbliższej dla świadka, występującej w charakterze współoskarżonego ${ }^{20}$. Natomiast fakt skorzystania przez osobę najbliższą dla oskarżonego z prawa odmowy zeznań nie oznacza automatycznego wyłączenia możliwości poddania takiej osoby, za jej zgodą, badaniom, o których mowa w art. $192^{21}$.

Z kolei zgodnie z treścią art. 183 §1 i 2 k.p.k. świadek może uchylić się od odpowiedzi na pytanie, jeżeli udzielenie odpowiedzi mogłoby narazić jego lub osobę dla niego najbliższą na odpowiedzialność za przestępstwo lub przestępstwo skarbowe. Świadek może żądać, aby przesłuchano go na rozprawie z wyłączeniem jawności, jeżeli treść zeznań mogłaby narazić na hańbę jego lub osobę dla niego najbliższą. W tym przypadku istotne znaczenie ma fakt, iż świadek nie ma obowiązku podawania powodów, z jakich odmawia odpowiedzi na pytanie, a wystarczające jest, że powoła się na przepis art. 183 §1 k.p.k. i tym samym może uchylić się od odpowiedzi na pytanie. Organ procesowy nie może żądać od świadka, aby ujawnił motywy, jakimi kieruje się, uchylając się od odpowiedzi na konkretne pytanie ${ }^{22}$.

Zgodnie z przepisem art. 185 k.p.k. można zwolnić od złożenia zeznania lub odpowiedzi na pytania osobę pozostającą z oskarżonym w szczególnie bliskim stosunku osobistym, jeżeli osoba taka wnosi o zwolnienie. Wskazany przepis dopuszcza możliwość zwolnienia świadka, na jego wniosek, od składania zeznań lub udzielenia odpowiedzi na określone pytanie/pytania. Zgodnie $\mathrm{z}$ tą regulacją podstawę zwolnienia stanowi szczególnie bliski stosunek osobisty łączący świadka z oskarżonym, któremu ustawodawca nadaje w konkretnej sytuacji wyższą wartość niż dobru wymiaru sprawiedliwości. Przepis art. 183 k.p.k. znajduje zastosowanie zarówno w postępowaniu przygotowawczym, jak też na etapie rozpoznawania sprawy przez sąd. Obowiązek uprzedzenia świadka o uprawnieniu do złożenia wniosku o zwolnienie z zeznania lub odpowiedzi na pytanie powstaje jedynie wówczas, gdy ujawni się okoliczność uzasadniająca zwolnienie, jednakże nie później niż przed pierwszym przesłuchaniem na rozprawie w I instancji (art. 191 §2 k.p.k. w zw. z art. 186 §1 k.p.k.). Natomiast ustawodawca wyłączył możliwość zaskarżenia postanowienia organu $\mathrm{w}$ tym przedmiocie.

Osoba składająca wniosek o zwolnienie musi uprawdopodobnić istnienie "szczególnie bliskiego stosunku osobistego" z podejrzanym/oskarżonym. W doktrynie wskazuje się, iż za tego rodzaju stosunki mogą być uznane przede (red.), L. K. Paprzycki, S. Steinborn, op. cit.

22 333407. 
wszystkim społecznie akceptowane lub tolerowane osobiste związki i powiązania, których nie można zaliczyć do stosunku najbliższości, uzasadniającego skorzystanie $\mathrm{z}$ uprawnienia określonego $\mathrm{w}$ art. 183 k.p.k. Tytułem przykładu wskazać więc należy na stan narzeczeństwa, pozostawanie we wspólnym pożyciu osób tej samej płci, pokrewieństwo czy powinowactwo z konkubentem oskarżonego, były konkubinat, a także przyjaźń. Dla skorzystania z uprawnienia przewidzianego $\mathrm{w}$ tym przepisie nie ma znaczenia moment powstania stosunku osobistego, jednakże musi on istnieć w momencie występowania o zwolnienie i być już „szczególnie bliski”23. Szczególnie bliski stosunek osobisty (art. 185 k.p.k.) może wynikać np. z faktu posiadania wspólnego dziecka przez osobę składającą zeznania i podejrzanego bądź oskarżonego ${ }^{24}$.

Z kolei przepis art. $261 \S 1$ k.p.k. stanowi, iż o zastosowaniu tymczasowego aresztowania sąd obowiązany jest bezzwłocznie zawiadomić osobę najbliższą dla oskarżonego, wskazaną przez niego. Na wniosek oskarżonego można również zawiadomić inną osobę zamiast lub obok wskazanej w §1 (art. 261 §2 k.p.k.). Powołany przepis daje zatem możliwość zawiadomienia o tymczasowym aresztowaniu także partnera/partnerki osób pozostających w związkach partnerskich, niezależnie od tego, czy są to związki homo-, czy heteroseksualne. Wprawdzie przepis art. $261 \S 1$ in fine mówi jedynie, że spośród osób najbliższych może to być osoba wskazana przez oskarżonego, ale należy przyjąć, że sąd powinien zawiadamiać inną osobę tylko w wyjątkowych przypadkach albo gdy nie ma kontaktu z osobą najbliższą wskazaną przez oskarżonego. W doktrynie wskazuje się także, iż, pomimo brzmienia art. $261 \S 2$ k.p.k., nie można odmówić uwzględnienia wniosku oskarżonego o zawiadomienie, zamiast lub obok osoby najbliższej, innej osoby. W tym przypadku nie chodzi bowiem o swobodne uznanie sądu stosującego tymczasowe aresztowanie, a o uprawnienie oskarżonego i korespondujący z tym uprawnieniem obowiązek sądu ${ }^{25}$.

Zgodnie z treścią art. $266 \S 1$ k.p.k. poręczenie majątkowe może złożyć oskarżony albo inna osoba. Wobec braku ograniczenia kręgu osób, które mogą złożyć poręczenia majątkowe za podejrzanego/oskarżonego nie ulega wątpliwości, iż tego rodzaju środek zapobiegawczy może złożyć także partner/partnerka pozostająca $\mathrm{z}$ podejrzanym/oskarżonym $\mathrm{w}$ związku partnerskim homoseksualnym.

O osobie najbliższej albo zamieszkującej wspólnie z podejrzanym/oskarżonym mowa jest również $\mathrm{w}$ art. 275 §3 k.p.k. W myśl powołanego przepisu, jeżeli zachodzą przesłanki zastosowania tymczasowego aresztowania wobec

T. Grzegorczyk, Kodeks postępowania karnego. Komentarz, Zakamycze 2003.

Postanowienie Sądu Najwyższego z 22 lutego 2006 r., III KK 222/05, „Prokuratura i Prawo” - wkł. 2007/3/5.

5 L. K. Paprzycki, op. cit. 
oskarżonego o przestępstwo popełnione z użyciem przemocy lub groźby bezprawnej na szkodę osoby najbliższej albo innej osoby zamieszkującej wspólnie ze sprawcą, zamiast tymczasowego aresztowania można zastosować dozór, pod warunkiem, że oskarżony w wyznaczonym terminie opuści lokal zajmowany wspólnie z pokrzywdzonym oraz określi miejsce swojego pobytu. Uznać zatem należy, iż osobie zamieszkującej wspólnie z podejrzanym/oskarżonym, niezależnie od tego, jakiego rodzaju relacje ich łączą, przysługuje uprawnienie do złożenia wniosku o zastosowanie tego rodzaju środka zapobiegawczego.

Dodatkowo - na podstawie art. 275a k.p.k. - tytułem środka zapobiegawczego można nakazać oskarżonemu o przestępstwo popełnione $\mathrm{z}$ użyciem przemocy na szkodę osoby wspólnie zamieszkującej opuszczenie lokalu mieszkalnego zajmowanego wspólnie z pokrzywdzonym, jeżeli zachodzi uzasadniona obawa, że oskarżony ponownie popełni przestępstwo $\mathrm{z}$ użyciem przemocy wobec tej osoby, zwłaszcza gdy popełnieniem takiego przestępstwa groził. Wprawdzie w postępowaniu przygotowawczym tego rodzaju środek zapobiegawczy stosuje się na wniosek Policji albo z urzędu, jednakże nie ma przeszkód, aby osoba zamieszkująca z podejrzanym przejawiała inicjatywę $\mathrm{w}$ tej kwestii i wystąpiła do Policji lub prokuratora o jego zastosowanie.

Kolejną grupę uprawnień stanowią uprawnienia związane z uczestnictwem partnera/partnerki w postępowaniu karnym, niezależnie od tego, w jakim charakterze/roli występuje $\mathrm{w}$ tym postępowaniu.

Osoba pozostająca w związku partnerskim, zamieszkująca wspólnie z uczestnikiem postępowania karnego, może bowiem odbierać kierowane do niego pisma procesowe. Uprawnienie takie statuuje przepis art. 132 \$2 k.p.k., stanowiąc, iż $\mathrm{w}$ razie chwilowej nieobecności adresata $\mathrm{w}$ jego mieszkaniu pismo doręcza się dorosłemu domownikowi, jeżeli podejmie się oddać pismo adresatowi. Co istotne, domownik nie musi dysponować żadnym pisemnym upoważnieniem do odbioru pism, gdyż jego legitymacja w tym zakresie wynika wprost z powołanego przepisu ustawy.

Status „domowników” adresata pisma (art. 43 k.p.a.) mają zamieszkujący $\mathrm{z}$ nim $\mathrm{w}$ jednym mieszkaniu lub domu jego dorośli krewni i powinowaci, niezależnie od tego, czy równocześnie prowadzą z nim wspólne gospodarstwo domowe. Natomiast osoby obce adresatowi nie są jego domownikami, nawet gdy mieszkają $\mathrm{w}$ tym samym mieszkaniu (np. jako lokatorzy lub sublokatorzy), chyba że zostały przez adresata włączone do wspólnoty domowej i prowadzą z nim (jego rodziną) wspólne gospodarstwo ${ }^{26}$. Nie jest natomiast wymagane, aby domownik był zameldowany w mieszkaniu adresata. Sławomir Steinborn zwraca uwagę, iż $\mathrm{w}$ orzecznictwie i piśmiennictwie przeważa pogląd, że określenie "dorosły domownik" stanowi potoczny odpowiednik prawnego 
określenia osoby pełnoletniej $\mathrm{w}$ rozumieniu art. 10 k.c. Warto jednak zwrócić uwagę, że ustawodawca w przepisach kodeksu postępowania karnego posługuje się zarówno pojęciem „pełnoletni”, jak i „małoletni”, a zatem użyty w komentowanym przepisie termin "dorosły" nie jest przypadkowy. Wydaje się bowiem, że chodzi tu nie tylko o osobę pełnoletnią, ale jednocześnie taką, która z uwagi na swój rozwój umysłowy daje rękojmię zdawania sobie sprawy w aktu doręczenia i poinformuje adresata o zdarzeniu, które miało miejsce podczas jego nieobecności ${ }^{27}$.

Osoba pozostająca w związku partnerskim może uzyskać wgląd w akta postępowania przygotowawczego. Zgodnie bowiem $\mathrm{z}$ treścią art. $156 \S 5$ zd. 2 k.p.k. $\mathrm{w}$ toku postępowania przygotowawczego, za zgodą prokuratora, akta mogą być w wyjątkowych przypadkach udostępnione innym (niż strony postępowania i ich pełnomocnicy) osobom. W tym przypadku nie ma znaczenia, jakiego rodzaju relacje łączą daną osobę ze stronami postępowania. Jednocześnie należy jednak zaznaczyć, iż taka osoba może jedynie zapoznać się $\mathrm{z}$ dokumentami znajdującymi się $\mathrm{w}$ aktach postępowania przygotowawczego, nie ma natomiast prawa do sporządzania odpisów i kserokopii $z$ tych akt oraz uzyskania uwierzytelnionych odpisów i kserokopii ${ }^{28}$. Ponadto, na podstawie art. $156 \S 1$ zd. 2 k.p.k. osoby inne niż strony postępowania karnego i ich pełnomocnicy mogą uzyskać również dostęp do akt sprawy karnej już po jej przekazaniu do sądu, na etapie postępowania jurysdykcyjnego. Wówczas podmiotem uprawnionym do wyrażenia zgody na udostępnienie akt jest prezes sądu.

Osoby pozostające $\mathrm{w}$ związkach partnerskich mogą również uczestniczyć w rozprawach, w których ich partner jest stroną lub którego sprawa dotyczy. Zgodnie bowiem z treścią art. 355 k.p.k. rozprawa odbywa się jawnie i mogą w niej uczestniczyć osoby pełnoletnie (art. 356 §1 k.p.k.).

Przedstawione powyżej różne możliwości udziału osób pozostających $\mathrm{w}$ związkach partnerskich hetero- $\mathrm{i}$ homoseksualnych $\mathrm{w}$ postępowaniu karnym oraz zakres przysługujących im $\mathrm{w}$ toku tego postępowania uprawnień prowadzi do wniosku, iż kluczowe znaczenie ma termin "osoba najbliższa", unormowany $\mathrm{w}$ art. $115 \S 11$ k.k. Z uwagi jednak na fakt, iż nie ma on ustalonego znaczenia $\mathrm{w}$ języku prawniczym, skutkuje to różną interpretacją oraz różnym zakresem wskazanych powyżej karnoprocesowych możliwości pozostających we wspólnym pożyciu osób różnej oraz tej samej płci. Natomiast stwierdzenie to nie uprawnia $w$ żaden sposób do wysuwania kategorycznej tezy, że na gruncie przepisów kodeksu postępowania karnego można mówić

27 S. Steinborn, Komentarz aktualizowany do art. 132 Kodeksu postepowania karnego, [w:] J. Grajewski (red.), L. K. Paprzycki, S. Steinborn, op. cit.

28 Idem, Komentarz aktualizowany do art. 156 Kodeksu postępowania karnego, [w:] J. Grajewski (red.), L. K. Paprzycki, S. Steinborn, op. cit. 
o dyskryminacji osób tworzących związki partnerskie. Nie sposób jednak nie zauważyć, iż dominujące $\mathrm{w}$ doktrynie i orzecznictwie wąskie rozumienie pojęcia pozostawania we wspólnym pożyciu i zaliczanie do tej kategorii wyłącznie konkubinatów powoduje ograniczenie praw osób pozostających w homoseksualnych związkach partnerskich w zakresie uprawnień pokrzywdzonego. Powyższe rozważania wpisują się niewątpliwie w nurt aktualnie dyskutowanych zagadnień z zakresu prawa karnego procesowego.

\section{Bibliografia}

\section{Literatura}

Doda Z., Gaberle A., Dowody w procesie karnym, Warszawa 1995.

Gajek J., O pojęciu faktycznego wspólnego pożycia w prawie karnym, „Palestra” 1972, nr 3.

Grajewski J. (red.), Steinborn S., Komentarz aktualizowany do art. 58 Kodeksu postępowania karnego [w:] J. Grajewski (red.), L. K. Paprzycki, S. Steinborn, Komentarz aktualizowany do art. 1-424 ustawy z dnia 6 czerwca 1997 r. Kodeks postępowania karnego (Dz. U. 97.89.555), LEX/el., 2013.

Grzegorczyk T., Kodeks postępowania karnego. Komentarz, Zakamycze 2003.

Majewski J., [w:] A. Zoll, G. Bogdan, Z. Ćwiąkalski, P. Kardas, J. Majewski, J. Raglewski, M. Szewczyk, W. Wróbel, Kodeks karny. Część ogólna. Komentarz, t. 1: Komentarz do art. 1-116 k.k., Kraków 2004.

Marek A., Komentarz do kodeksu karnego. Część ogólna, Warszawa 1999.

Mozgawa M. (red.), Budyn-Kulik M., Kozłowska-Kalisz P., Kulik M. Kodeks karny. Komentarz, teza 4 do art. 115 §11 k.k., Lex, 2013.

Siewierski M. [w:] J. Bafia, K. Mioduski, M. Siewierski, Kodeks karny. Komentarz, Warszawa 1971.

Siostrzonek-Sergiel A., Partnerzy w zwiazkach homoseksualnych a "osoby najbliższe" w prawie karnym, PiP 2011, z. 4.

Wojciechowski J., Kodeks karny. Komentarz. Orzecznictwo, Warszawa 1997.

Wolter W., [w:] I. Andrejew, W. Świda, W. Wolter, Kodeks karny z komentarzem, Warszawa 1973.

Zoll A., [w:] A. Zoll, G. Bogdan, Z. Ćwiąkalski, P. Kardas, J. Majewski, J. Raglewski, M. Szewczyk, W. Wróbel, Kodeks karny. Część ogólna. Komentarz, t. 1: Komentarz do art. 1-116 k.k., Kraków 2004.

\section{Orzecznictwo}

Wyrok SN z 12 listopada 1975 r., V KR 203/75, OSP 1976, z. 10, poz. 187. 
Wyrok SN z 31 marca 1988 r., I KR 50/88, OSNKW 1988, nr 9-10, poz. 71.

Postanowienie SN z 13 listopada 1996 r., III RN 27/96, OSNP 1997, nr 11, poz. 187.

Postanowienie SN z 7 lipca 2004 r., II KK 176/04, LEX nr 121668.

Postanowienie Sądu Najwyższego z 8 lutego 2006 r., IV KK 394/05, OSNwSK 2006/1/306, LEX 333407.

Wyrok SA w Szczecinie z 21 grudnia 2006 r., II AKa 157/06, LEX nr 283401.

Wyrok SA w Katowicach z 15 marca 2007 r., II AKa 24/07, „Prokuratura i Prawo” $2007 / 11 / 26$.

Postanowienie SN z 26 października 2011 r., I KZP 11/11, „Prokuratura i Prawo” wkł. 2012/1/3.

Wyrok SA w Krakowie z 17 listopada 2011 r., II Aka 220/11, KZS 2011, z. 11, poz. 36.

Postanowienie SN z 4 lipca 2012 r., III KK 162/12, „Prokuratura i Prawo” - wkł. 2013/2/6. 